\title{
MINERALS COMPOSITION AND CHARACTERIZATION OF THE HATCHERY EGGSHELL WASTE TREATED WITH DIFFERENT PREPARATION METHODS
}

\author{
Ahmad Iskandar Setiyawan ${ }^{1)}$, Diah Pratiwi ${ }^{1)}$, Mohammad Faiz Karimy ${ }^{1)}$, Safna Fauziah ${ }^{1)}$ \\ 1) Research Unit for Natural Product Technology (BPTBA) BRIN Yogyakarta Jl Jogja-Wonosari Km 31,5 \\ Gading, Playen, Gunungkidul Yogyakarta \\ *Corresponding Email: ahmd.setiyawan@gmail.com
}

Submitted 16 September 2021; Accepted 27 November 2021

\begin{abstract}
The preparation process needs to be carried out in the treatment of hatchery waste. The objective of the study was to determine the mineral content and characterization of the eggshell waste after preparation. An experiment was arranged on a completely randomized design (CRD). Preparation treatment consisted of; T1: shell waste watered with distilled water; T2: shell waste soaked in distilled water for $12 \mathrm{~h}$; T3: shell waste soaked in $0.5 \% \mathrm{NaOH}$ for 720 min; and T4: shell waste boiled at $80^{\circ} \mathrm{C}$ for $15 \mathrm{~min}$ and soaked in $5 \% \mathrm{H}_{3} \mathrm{PO}_{4}$ for $15 \mathrm{~min}$. The data were analyzed using Analysis of Variance (ANOVA), and if any differences, a Duncan Multiple Range Test (DMRT) post hoc tests were carried out. Composition of proximate and mineral were detected by using X-Ray Fluorescence (XRF). Results indicated that proximate analysis of the dry matter content were T4: $98.98 \pm 0.01$; T3: $98.58 \pm 0.04$; T2: $98.75 \pm 0.08$; and T1: $98.72 \pm 0.03$. The calcium content of the treatment from the highest was T3: $24.22 \pm 0.31$; T1: $22.80 \pm 0.57$; T2: $22.77 \pm 0.71$; and T4: $21.55 \pm 0.46$. It may be inferred that the treatment technique had no major impact on the eggshells physical characteristics. However, boiling treatment at $80^{\circ} \mathrm{C}$ for $15 \mathrm{~min}$ and soaking in $5 \% \mathrm{H}_{3} \mathrm{PO}_{4}$ reduced the eggshell waste's $\mathrm{Mg}, \mathrm{Si}$, and $\mathrm{Ca}$ content. The addition of $0.5 \% \mathrm{NaOH}$ immersion did not degrade $\mathrm{Mg}, \mathrm{Ca}$, and $\mathrm{Si}$ of eggshell waste.
\end{abstract}

Keywords: Calcium; eggshell; proximate; silica; XRF 


\section{INTRODUCTION}

The population of poultry in Gunungkidul Regency in 2020 has increased, especially broilers. The broiler population increased from 1,626,260 to 1,635,000 (BPS, 2020). Population increase is directly proportional to the population of day-old chicks as well as eggshell production. Eggshell was part of the waste that had not been handled properly. Mittal et al. (2016) explained that the largest contribution of waste is from eggshells of hatcheries.

The survey conducted in Gunungkidul Regency has two hatcheries with a production capacity of 100,000 hatching eggs/month. Hatchery waste was not only shells, infertile eggs, dead embryos, cracked eggs, failed chicks to hatch, or culling chicks (Dhaliwal et al., 1997; Glatz et al., 2011). Environmental pollution, odors, flies, and problems with eggshell waste disposal and zoonoses are negative impacts if the waste is not handled (Glatz et al., 2011; Orrico et al., 2020). According to Khairiyah (2016), zoonoses are diseases transmitted from animals to humans and vice versa. For this reason, before processing eggshell waste, it is necessary to sterilize it. Kismiati et al. (2013) explained that using 3-5\% phosphoric acid $\left(\mathrm{H}_{3} \mathrm{PO}_{4}\right)$ could reduce eggshell bacteria.

However, it has not been explained the effect of preparation on the mineral content of the eggshell. According to Setiyawan et al. (2021), hatchery eggshells contain $22.52 \% \mathrm{Ca}, 0.56 \% \mathrm{Mg}$, and $0.19 \% \mathrm{P}$. The mineral content in the shell has the potential to be utilized. Minerals in the shell are usually bound to several other compounds or

*Corresponding author:

Ahmad Iskandar Setiyawan

Email: ahmd.setiyawan@gmail.com

Research Unit for Natural Product Technology

(BPTBA) BRIN Yogyakarta Jl Jogja-Wonosari Km

31,5 Gading, Playen, Gunungkidul Yogyakarta components (Wowor et al., 2015). According to Yonata et al., (2017), the use of the solution can affect the mineral content in the shell. It was further explained that the use of $\mathrm{HCl}$ as a solution to soak the shells reduced the calcium content by $2 \%$. Based on the description above, a review of the hatchery eggshell preparation material was carried out. This research aimed to determine the mineral content and characterization of the eggshell waste after preparation with different solvents.

\section{MATERIALS AND METHODS}

The research was conducted in the Research Division for Natural Product Technology laboratory, The National Research and Innovation Agency. Eggshell samples were obtained from the hatchery of PT Widodo Makmur Unggas in Semanu sub-district, Gunungkidul district. In addition to the eggshell material samples, chemicals that were also used for proximate analysis included aquades, $0.5 \% \mathrm{NaOH}, 5 \%$ $\mathrm{H}_{3} \mathrm{PO}_{4}$, and cellulose for X-Ray Fluorescence (XRF) preparation. The equipment used was a digital scale with a capacity of $5 \mathrm{~kg}$, a beaker glass, hydraulics for sample pressing (XRF preparation), and a set of proximate analyzers.

\section{Research Methods}

The study was conducted using a completely randomized design method (CRD) with preparation treatments (T). T1: shell waste was flushed with distilled water; T2: shell waste soaked in distilled water for $12 \mathrm{~h}$; T3: shell waste soaked in $\mathrm{NaOH} 0.5 \%$ for $720 \mathrm{~min}$; and T4: shell waste was boiled at $80^{\circ} \mathrm{C}$ for $15 \mathrm{~min}$ and soaked in $5 \% \mathrm{H}_{3} \mathrm{PO}_{4}$

\section{How to cite:}

Setiyawan, A. I., Pratiwi, D., Karimy, M. F., \& Fauziah, S. (2021). Minerals Composition and Characterization of the Hatchery Eggshell Waste Treated with Different Preparation Methods. Jurnal Ilmu dan Teknologi Hasil Ternak (JITEK), 16 (3), 144-152 
for $30 \mathrm{~min}$ referring to the eggshell preparation method of Kismiati et al. (2013). After the sample treatment, milling was carried out with a size of 20 mesh before analysis. Then a proximate analysis was carried out (AOAC, 2005). XRF analysis was carried out to determine the elements contained in eggshells. Before testing the sample, preparation was carried out first. First, the milled and sifted samples were mixed with cellulose in a ratio of $7: 1$. Then, it was mixed until homogeneous and pressed using hydraulics. After that, readings were carried out using an XRF device with the brand Epsilon 4 made by Malvern Panalytical.

Fourier transform infrared (FTIR) analysis was carried out to determine the functional group of eggshells. IR spectra of treatments were then recorded by FTIR model Bruker Vertex 80 in the range of 500$4000 \mathrm{~cm}^{-1}$. Eggshell profiles using SEM (Hitachi SU 3500) at the same magnification, namely $1 \mathrm{~K}$ with Vacc $3 \mathrm{kV}$, and previously prepared by coating with gold $(\mathrm{Au})$ using an ion device Sputter MC1000 (Hitachi Corp.) (Suryani et al., 2021). They set parameters for the Hitachi SU3500 SEM and eggshell sample preparation using modified (Karimy et al., 2020; Prasetyo et al., 2019) techniques.

\section{Data Analysis}

The data were analyzed using Analysis of Variance (ANOVA); when significant, a Duncan Multiple Range Test
(DMRT) post hoc tests were carried out. Data analysis was performed using the SPSS application for Windows 16.0.

\section{RESULTS AND DISCUSSION}

\section{Proximate Composition}

Dry matter was the content of materials that had been removed from the water. Treatment T4 has the highest dry matter content than T3 (Table 1). There was a correlation between the water content and the content of organic or non-organic materials in a material (Soekarto, 2012). Further explained, dry matter such as carbohydrates, proteins, fats, and vitamins can bind water. The decrease in protein content using $\mathrm{H}_{3} \mathrm{PO}_{4}$ solution was possible to reduce the water content of the material so that the dry matter content increased.

Ash content was the value of inorganic materials in a material. The inorganic material content of $\mathrm{T} 1$ was lower $(90.37 \pm 0.76 \%)$ than the other methods. This value indicates that $\mathrm{T} 1$ still contains organic material. It can be seen from the value of crude protein content $(7.88 \pm 0.06 \%)$ of the method. For the T4 preparation method, the inorganic material content was not different from the T1 and T3 methods. According to Nurhidayah et al. (2019), inorganic materials were mineral components. The mineral components of eggshell waste used the T2, T3, and T4 preparation methods, namely $91.54 \pm 0.66 \%, 91.07 \pm 0.14 \%$, and $92.01 \pm 0.75 \%$.

Tabel 1. Proximate composition of hatchery eggshell waste with different preparation methods

\begin{tabular}{lcccc}
\hline Variable & T1 & T2 & T3 & T4 \\
\hline DM $(\%)$ & $98.72 \pm 0.03^{\mathrm{b}}$ & $98.75 \pm 0.08^{\mathrm{b}}$ & $98.58 \pm 0.04^{\mathrm{a}}$ & $98.98 \pm 0.01^{\mathrm{c}}$ \\
Ash (\%) & $90.37 \pm 0.76^{\mathrm{a}}$ & $91.54 \pm 0.66^{\mathrm{ab}}$ & $91.07 \pm 0.14^{\mathrm{ab}}$ & $92.01 \pm 0.75^{\mathrm{b}}$ \\
EE $(\%)$ & $0.07 \pm 0.00$ & $0.07 \pm 0.01$ & $0.07 \pm 0.02$ & $0.07 \pm 0.02$ \\
CF $(\%)$ & $0.51 \pm 0.01^{\mathrm{a}}$ & $0.59 \pm 0.02^{\mathrm{b}}$ & $0.58 \pm 0.02^{\mathrm{b}}$ & $0.79 \pm 0.01^{\mathrm{c}}$ \\
CP $(\%)$ & $7.88 \pm 0.06^{\mathrm{c}}$ & $6.72 \pm 0.32^{\mathrm{b}}$ & $6.92 \pm 0.27^{\mathrm{b}}$ & $4.18 \pm 0.27^{\mathrm{a}}$ \\
\hline
\end{tabular}

Remarks : *Mean values in same row with the different letters are significantly different at $\mathrm{p}<$ 0.05-T1: shell waste was flushed with distilled water; T2: shell waste soaked in distilled water for $12 \mathrm{~h}$; T3: shell waste soaked in $\mathrm{NaOH} 0.5 \%$ for $12 \mathrm{~h}$; and T4: shell waste was boiled at $80^{\circ} \mathrm{C}$ for $15 \mathrm{~min}$ and soaked in $5 \% \mathrm{H}_{3} \mathrm{PO}_{4}$ for $30 \mathrm{~min}$. DM : dry matter; $\mathrm{EE}$ : extract eter; $\mathrm{CF}$ : crude fiber; $\mathrm{CP}$ : crude protein. 
The protein content of eggshell waste with different preparation methods contains a protein content of $4.18 \%-7.88 \%$. The protein content of eggshells treated by $\mathrm{T} 4$ was lower protein content than others. It was closely related to boiling and soaking $\mathrm{H}_{3} \mathrm{PO}_{4}$. Kismiati et al. (2013) stated that soaking with $\mathrm{H}_{3} \mathrm{PO}_{4}$ causes the eggshell to be a hollower. It can be seen from the particle size of T4, which was smaller and uniform than the other treatments (Figure 4). Therefore, changes in the structure and content of eggshells may occur. In addition, the heating process will cause the protein to be denatured. The heating process starting from $80^{\circ} \mathrm{C}$ reduces the protein content at a temperature of $70^{\circ} \mathrm{C}(37.54 \% \mathrm{CP})$ to $80^{\circ} \mathrm{C}$ (28.40\% CP) (Novia et al., 2011).

The T3 and T2 preparation methods also reduce the protein content of eggshell waste. $\mathrm{NaOH}$ was an alkaline solution that was used as a deproteination agent. The use of $\mathrm{NaOH}$ affects the deproteination reaction that causes changes in protein structure (Rohyami and Istiningrum, 2016). Hatchery eggshell waste contains a shell membrane containing protein. The eggshell membrane contains collagen (Cordeiro and Hincke, 2012). Protein is a compound that comes from several molecules $(\mathrm{C}, \mathrm{H}, \mathrm{O}, \mathrm{N})$, then it is hydrolyzed by water molecules (Paramita, 2013). Fiber content was divided into two types i.e., soluble and insoluble fiber. Insoluble fibers were cellulose, hemicellulose, and lignin (Mudgil, 2017). Eggshell waste contains more insoluble fiber. Therefore, T4 treatment increased the fiber content in shell waste. Furthermore, as described above, the treatment loosens the structure of the eggshell to release the bonds between the fibers (Kismiati et al., 2013). Likewise, the process of soaking with water and $\mathrm{NaOH}$ changes the structure of eggshell waste.

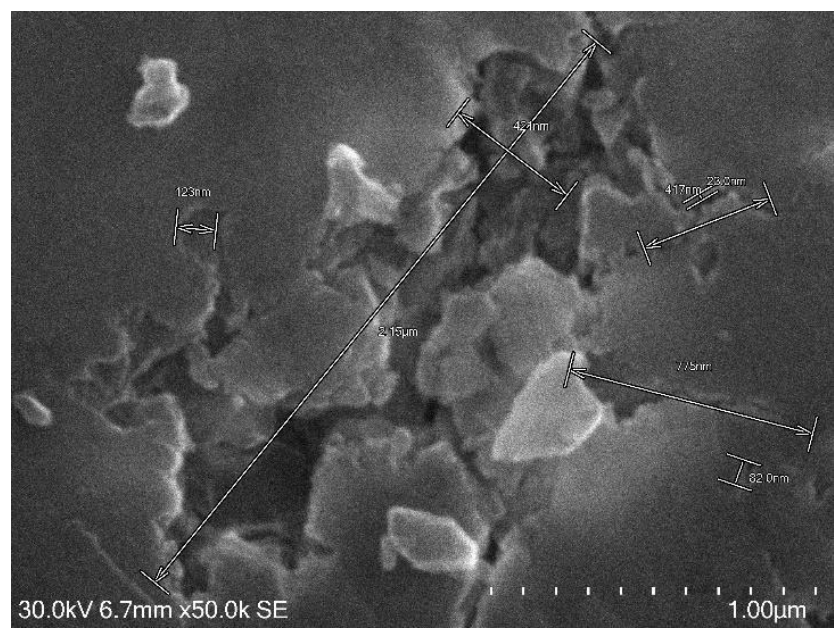

Figure 1. Fractional width of eggshell waste was boiled at $80^{\circ} \mathrm{C}$ for $15 \mathrm{~min}$ and soaked in $5 \%$ $\mathrm{H}_{3} \mathrm{PO}_{4}$ for 30 min.

\section{Eggshell waste mineral content}

Components of organic compounds have $\mathrm{C}, \mathrm{H}, \mathrm{O}$, and $\mathrm{N}$ (Sriharti \& Salim, 2010). These components are found in the structure of carbohydrates, proteins, fats, and fibers. The T3 and T4 methods were the lowest $\mathrm{C}, \mathrm{H}, \mathrm{O}, \mathrm{N}$ components (Table 2). In this treatment, the protein content decreased, especially the use of the T4 method (Table 1). Protein contains the element $\mathrm{N}$ in it (Uauy et al., 2015). Therefore, the low protein content indicates the low $\mathrm{N}$ content in the sample. The deproteination process by $0.5 \% \mathrm{NaOH}$ and boiling at $80^{\circ} \mathrm{C}$ then soaked with $5 \% \mathrm{H}_{3} \mathrm{PO}_{4}$ for 15 min reduced $\mathrm{CHON}$ levels.

The mineral content of the XRF detection results showed a significant difference between the four treatments. $80^{\circ} \mathrm{C}$ boiling treatment and $5 \% \mathrm{H}_{3} \mathrm{PO}_{4}$ immersion (T4) showed that the Ca content was lower than the others. Compared with 
the use of $0.5 \% \mathrm{NaOH}(\mathrm{T} 3)$, with a $\mathrm{Ca}$ content of $24.22 \pm 0.31 \%$. The decrease in mineral content in $\mathrm{T} 4$ can release the bonds that bind these minerals to dissolve in water. Nurlaela et al. (2014) stated that $94-97 \%$ Ca in the shell is $\mathrm{CaCO}_{3}$.

Tabel 2. XRF analysis of hatchery eggshell waste with different preparation methods.

\begin{tabular}{lcccc}
\hline Parameter & T1 & T2 & T3 & T4 \\
\hline CHON $(\%)$ & $76.17 \pm 0.60^{\mathrm{b}}$ & $76.15 \pm 0.66^{\mathrm{b}}$ & $74.47 \pm 0.34^{\mathrm{a}}$ & $74.44 \pm 0.65^{\mathrm{a}}$ \\
$\mathrm{Mg}(\%)$ & $0.20 \pm 0.01^{\mathrm{c}}$ & $0.18 \pm 0.01^{\mathrm{b}}$ & $0.22 \pm 0.00^{\mathrm{d}}$ & $0.14 \pm 0.01^{\mathrm{a}}$ \\
$\mathrm{Si}(\mathrm{ppm})$ & $89.15 \pm 9.75^{\mathrm{a}}$ & $88.00 \pm 0.70^{\mathrm{a}}$ & $144.75 \pm 31.35^{\mathrm{b}}$ & $106.55 \pm 17.45^{\mathrm{a}}$ \\
$\mathrm{P}(\%)$ & $0.16 \pm 0.01^{\mathrm{a}}$ & $0.17 \pm 0.01^{\mathrm{a}}$ & $0.15 \pm 0.01^{\mathrm{a}}$ & $2.89 \pm 0.17^{\mathrm{b}}$ \\
$\mathrm{Ca}(\%)$ & $22.80 \pm 0.57^{\mathrm{b}}$ & $22.77 \pm 0.71^{\mathrm{b}}$ & $24.22 \pm 0.31^{\mathrm{c}}$ & $21.55 \pm 0.46^{\mathrm{a}}$ \\
\hline
\end{tabular}

Remarks : *Mean values in same row with the different letters are significantly different at $\mathrm{p}<$ 0.05- T1: shell waste was flushed with distilled water; T2: shell waste soaked in distilled water for $12 \mathrm{~h}$; $\mathrm{T} 3$ : shell waste soaked in $\mathrm{NaOH} 0.5 \%$ for $12 \mathrm{~h}$; and T4: shell waste was boiled at $80^{\circ} \mathrm{C}$ for $15 \mathrm{~min}$ and soaked in $5 \% \mathrm{H}_{3} \mathrm{PO}_{4}$ for $30 \mathrm{~min}$. CHON : Carbon, Hydrogen, Oxygen, Nitrogen.

On the other hand, the decrease in calcium content increased the phosphorus (P) T4 content (Table 2). In addition to organic materials, eggshells contain inorganics such as calcium carbonate, magnesium carbonate, calcium phosphate, and magnesium phosphate (Laohavisuti et al., 2021). T4 eggshells were treated using acid. Calcium was easily degraded using acids (Amjad and Zuhl, 2007). It causes the release of bonds between calcium and phosphorus. So that the calcium content decreased and phosphorus increased.

Si (Silica) content in eggshells using $0.5 \% \mathrm{NaOH}$ preparation method was higher than other methods. $\mathrm{NaOH}$ was a deproteinizing agent that reduces collagen (protein) content marked by a decrease in the content of $\mathrm{C}, \mathrm{H}, \mathrm{O}, \mathrm{N}$ (Table 2.). However, it did not break the bonds of $\mathrm{Ca}$ and Si. According to Shen and Chen (2003), $\mathrm{Ca}$ served as a constituent of the palisade tissue, in the presence of Si can strengthen the tissue. It was further explained that the higher the amount of calcium, the more compact the shell layer.

Hatchery eggshell waste contains magnesium $(\mathrm{Mg})$. The $\mathrm{Mg}$ content of each treatment showed a significant difference among treatments. The T4 treatment tends to be lower than the other treatments. Acids very easily degrade magnesium. The use of inorganic compounds $\left(\mathrm{HCO}_{3}{ }^{-}, \mathrm{HPO}_{4}{ }^{2-}\right.$ and $\mathrm{H}_{2} \mathrm{PO}_{4}{ }^{-}$) can react and cause deposits (Gonzalez et al., 2018; Wang et al., 2017).

\section{FTIR Spectra of hatchery eggshell waste} FTIR was used to examine the structure and functional group of the samples. FTIR analysis was performed and compared for the hatchery eggshell waste with the different preparation methods, as presented in Figure 1. T1, T2, T3, and T4 samples presented similar spectra at around $1397 \mathrm{~cm}^{-1}, 1123 \mathrm{~cm}^{-1}, 872 \mathrm{~cm}^{-1}$, and $711 \mathrm{~cm}^{-}$

1 were associated with vibrations of carbonate $\left(\mathrm{CO}_{3}{ }^{2-}\right)$ groups (R. Ahmad et al., 2012; Wembabazi et al., 2015). Band $1397 \mathrm{~cm}^{-1}$ represented the asymmetric C-O stretch, $872 \mathrm{~cm}^{-1}$ represented the out of plane bend, and $711 \mathrm{~cm}^{-1}$ represented the in plane bend (Wembabazi et al., 2015). The band observed at $1060 \mathrm{~cm}^{-1}$ corresponds to the vibration of the phosphate group (A. Ahmad et al., 2020).

The peaks observed from the spectrum at around $3267 \mathrm{~cm}^{-1}$ suggest the presence of an amide group (Cheung, 2006). The spectrum followed the results of the proximate analysis in Table 1 . There was a tendency for spectrum results in $\mathrm{T} 4$ to be lower than other treatments. 


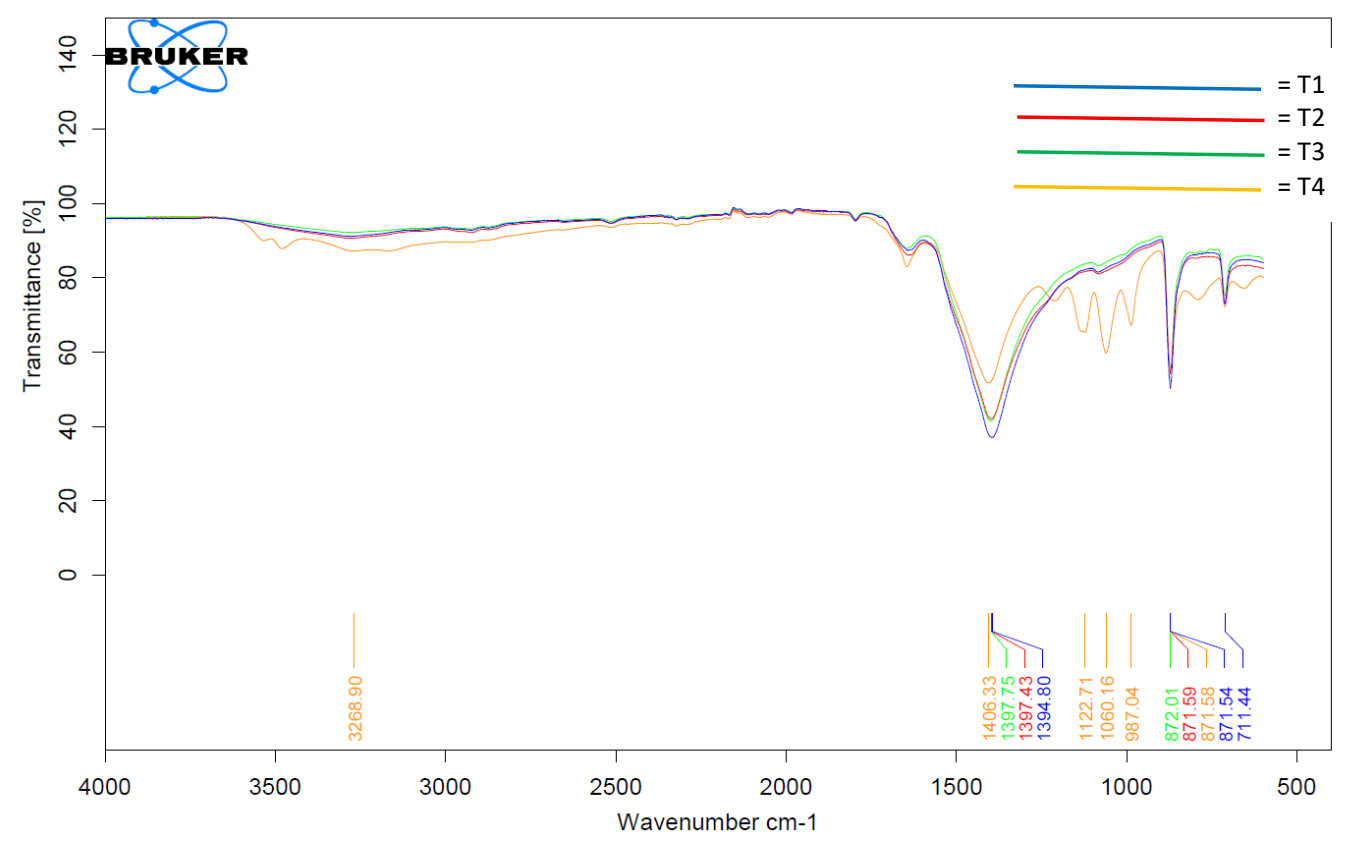

Figure 2. FTIR Spectra of hatchery eggshell waste with the different preparation methods

\section{Profile SEM of eggshell}

There was no significant variation in the profile of the SEM picture in the eggshell membrane samples seen by SEM with the tool configuration of magnification of 500 times, Vacc $30 \mathrm{kV}$, secondary electron (SE) detector, and high vacuum mode. The membrane fibres appear cleaner, and the membrane fibres form more noticeable in the $\mathrm{T} 4$ treatment.

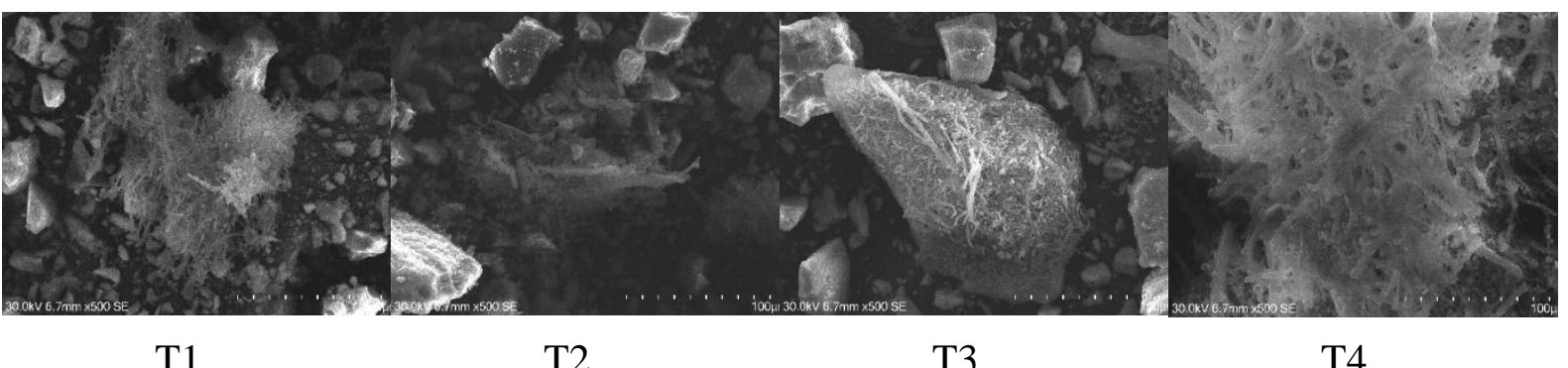

Figure 3. Eggshell membrane of hatchery eggshell waste with the different preparation methods. T1: shell waste was flushed with distilled water; T2: shell waste soaked in distilled water for $12 \mathrm{~h}$; T3: shell waste soaked in $\mathrm{NaOH} 0.5 \%$ for $12 \mathrm{~h}$; and T4: shell waste was boiled at $80^{\circ} \mathrm{C}$ for $15 \mathrm{~min}$ and soaked in $5 \% \mathrm{H}_{3} \mathrm{PO}_{4}$ for $30 \mathrm{~min}$.

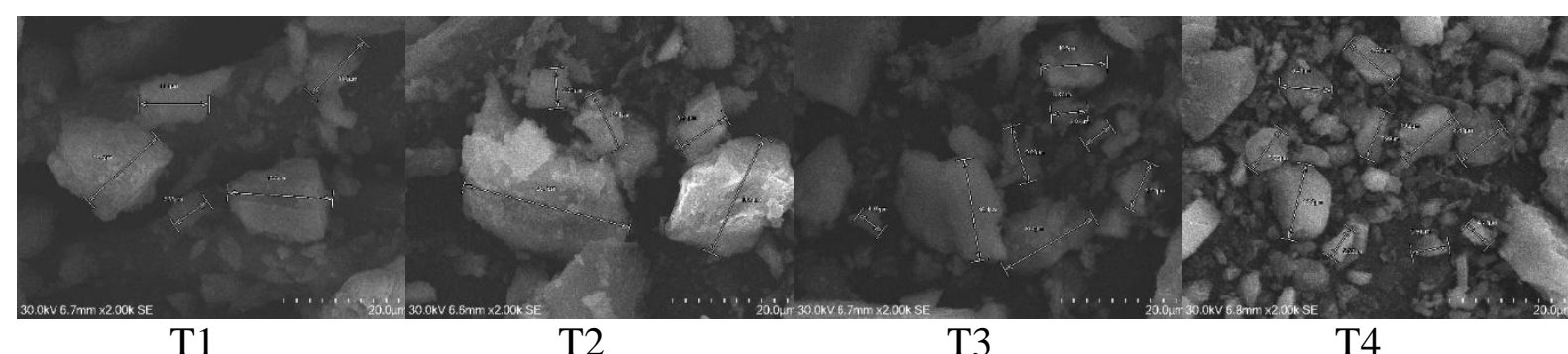

Figure 4. The particle of hatchery eggshell waste with the different preparation methods. T1: shell waste was flushed with distilled water; T2: shell waste soaked in distilled water for $12 \mathrm{~h}$; T3: shell waste soaked in $\mathrm{NaOH} 0.5 \%$ for $12 \mathrm{~h}$; and T4: shell waste was boiled at $80^{\circ} \mathrm{C}$ for $15 \mathrm{~min}$ and soaked in $5 \% \mathrm{H}_{3} \mathrm{PO}_{4}$ for $30 \mathrm{~min}$. 
When comparing the particle sizes of the eggshells amongst treatments T1, T2, $\mathrm{T} 3$, and $\mathrm{T} 4$, there were only minor differences in particle size. It can be seen from the description of the SEM particle size profile between treatments that the particle size is about the same, i.e. T1: particle size between 6.33-16.5 $\mu \mathrm{m}$, T2: particle size between 6.31-26.9 $\mu \mathrm{m}$, T3: particle size between 9.23-16.2 $\mu \mathrm{m}$, T4: particle size between 8.41-12.2 $\mu \mathrm{m}$. The particle size in the T3 and T4 treatments was more uniform than in the $\mathrm{T} 1$ and $\mathrm{T} 2$ treatments, with higher size fluctuations.

\section{CONCLUSION}

It may be inferred that the treatment technique had no major impact on the egg shell's physical characteristics. However, boiling treatment at $80^{\circ} \mathrm{C}$ for $15 \mathrm{~min}$ and soaking in $5 \% \mathrm{H}_{3} \mathrm{PO}_{4}$ reduced the eggshell waste's $\mathrm{Mg}, \mathrm{Si}$, and $\mathrm{Ca}$ content. The addition of $0.5 \% \mathrm{NaOH}$ immersion did not degrade $\mathrm{Mg}, \mathrm{Ca}$, and $\mathrm{Si}$ of eggshell waste. On this basis, it may be inferred that the treatment technique had no major impact on the egg shell's physical characteristics.

\section{ACKNOWLEDGMENT}

The authors would like to thank National Research Project Fiscal Year 2021, Indonesian Institute of Sciences.

\section{REFERENCES}

Ahmad, A., Jini, D., Aravind, M., Parvathiraja, C., Ali, R., Kiyani, M. Z., \& Alothman, A. (2020). A novel study on synthesis of egg shell based activated carbon for degradation of methylene blue via photocatalysis. Arabian Journal of Chemistry, 13(12), 8717-8722. https://doi.org/10.1016/j. arabjc.2020.10.002

Ahmad, R., Kumar, R., \& Haseeb, S. (2012). Adsorption of $\mathrm{Cu} 2+$ from aqueous solution onto iron oxide coated eggshell powder: Evaluation of equilibrium, isotherms, kinetics, and regeneration capacity. Arabian Journal of Chemistry, 5(3), 353-359. https:// doi.org/10.1016/j.arabjc.2010 .09 .003

Amjad, Z., \& Zuhl, R. W. (2007). Effect of heat treatment on the performance of deposit control polymers as calcium carbonate inhibitors. NACE International Corrosion Conference Series, 070561-0705618.

AOAC. (2005). Official Methods of Analysis of AOAC International. In Association of Official Analysis Chemists International (18th ed., Vol. 18). Association of Officiating Analytical Chemists.

BPS. (2020). Kabupaten Gunungkidul Dalam Angka 2020 (BPS (ed.)). BPS Badan Pusat Statistik Kabupaten Gunungkidul.

Cheung, A. (2006). A study of sequins on a Cantonese opera stage curtain. In The future of the 20th century: collecting, interpreting and conserving modern materials: postprints (pp. 122-127).

Cordeiro, C. M., \& Hincke, M. (2012). Recent Patents on eggshell: shell and membrane applications. Recent Patents on Food, Nutrition \& Agriculturee, 3(1), 1-8. https://doi. org/10.2174/2212798411103010001

Dhaliwal, A. P. S., Shingari, B. K., \& Sapra, K. L. (1997). Chemical composition of hatchery waste. Pakistan Vet. J., 17(4), 20-22.

Glatz, P., Miao, Z., \& Rodda, B. (2011). Handling and treatment of poultry hatchery waste: A review. Sustainability, 3(1), 216-237. https:// doi.org/10.3390/su3010216

Gonzalez, J., Hou, R. Q., Nidadavolu, E. P. S., Willumeit-Römer, R., \& Feyerabend, F. (2018). Magnesium degradation under physiological conditions - Best practice. Bioactive Materials, 3(2), 174-185. https://doi. org/10.1016/j.bioactmat.2018.01.003

Karimy, M. F., Damayanti, E., Suryani, A. E., Prasetyo, E., Nurhayati, R., Anwar, 
M., \& Anggraeni, A. S. (2020). A simple method for analysis of Saccharomyces cerevisiae morphology by applying a high vacuum mode of the scanning electron microscopy and without chemical fixatives. IOP Conference Series: Earth and Environmental Science, 462(1). https://doi.org/10.1088/ 17551315/462/1/012048

Khairiyah. (2016). Zoonosis dan upaya pencegahannya (kasus sumatera utara). Jurnal Penelitian Dan Pengembangan Pertanian, 30(3), 117-124. https://doi.org/10.21082/jp3 .v30n3.2011.p117-124

Kismiati, S., Yuwanta, T., Zuprizal, \& Supadmo. (2013). The microstructure of egg shell waste treated with $\mathrm{H} 3 \mathrm{PO} 4$, in vitro solubility in different particle size and the using effect on the egg shell quality of laying hens. International Journal of Poultry Science, 12(7), 421-425. https://doi. org/10.3923/ijps.2013.421.425

Laohavisuti, N., Boonchom, B., Boonmee, W., Chaiseeda, K., \& Seesanong, S. (2021). Simple recycling of biowaste eggshells to various calcium phosphates for specific industries. Scientific Reports, 11(1), 1-11. https:// doi.org/10.1038/s41598-02194643-1

Mittal, A., Teotia, M., Soni, R. K., \& Mittal, J. (2016). Applications of egg shell and egg shell membrane as adsorbents: A review. Journal of Molecular Liquids, 223, 376-387. https://doi.org/10.1016/j.molliq.2016. 08.065

Mudgil, D. (2017). The Interaction Between Insoluble and Soluble Fiber. Dietary Fiber for the Prevention of Cardiovascular Disease: Fiber's Interaction between Gut Micoflora, Sugar Metabolism, Weight Control and Cardiovascular Health, July 2017, 35-59. https://doi.org/10.1016/ B978-0-12-805130-6.00003-3

Novia, D., Melia, S., \& Ayuza, N. Z. (2011).
Kajian suhu pengovenan terhadap kadar protein dan nilai organoleptik telur asin. Jurnal Peternakan, 8(2), 70-76.

Nurhidayah, B., Soekendarsi, E., \& Erviani, A. E. (2019). Kandungan kolagen sisik ikan bandeng (chanos-chanos) dan sisik ikan nila (oreochromis niloticus. Biologi Makassar, 4(1), 39-47.

Nurlaela, A., Dewi, S. U., Dahlan, K., \& Soejoko, D. S. (2014). Pemanfaatan limbah cangkang telur ayam dan bebek sebagai sumber kalsium untuk sintesis mineral tulang. Jurnal Pendidikan Fisika Indonesia, 10(1), 81-85. https://doi.org/10.15294/jpfi.v $10 \mathrm{i} 1.3054$

Orrico, A. C. A., Schwingel, A. W., Costa, M. S. S. de M., Orrico Junior, M. A. P., Borquis, R. R. A., Alves, G. P., de Oliveira, J. D., Leite, B. K. V., Garcia, R. G., \& Vilela, R. N. da S. (2020). Characterization and valuing of hatchery waste from the broiler chicken productive chain. Waste Management, 105, 520-530. https:// doi.org/10.1016/j.wasman.2020.02.029

Paramita, O. (2013). Pengaruh jenis air perendam terhadap kandungan vitamin c, serat, dan protein tepung mangga (Mangifera Indica L.). Jurnal Bahan Alam Terbarukan, 2(1), 24-30. https://doi.org/10.15294/jbat.v2i1.2912

Prasetyo, E., Jatmiko, T. H., \& Karimy, M. F. (2019). Optimization study of charcoal observation with scanning electron microscope in various operating conditions. IOP Conference Series: Earth and Environmental Science, 251(1). https://doi.org/10.10 88/1755-1315/251/1/012010

Rohyami, Y., \& Istiningrum, R. B. (2016). Preparation of chitin, study of physicochemical properties and biopesticide activities. Eksakta, 13(12), 49-55. https://doi.org/10.20885/ eksakta.vol13.iss1-2.art6

Setiyawan, A. I., Karimy, M. F., \& Erwinda, Z. (2021). Karakteristik mikro struktur dan komposisi cangkang telur. 
Prosiding Seminar Teknologi Dan Agribisnis Peternakan VIII, Vol 8 (2021), 490-496.

Shen, T. F., \& Chen, W. L. (2003). The role of magnesium and calcium in eggshell formation in tsaiya ducks and leghorn hens. Asian-Australasian Journal of Animal Sciences, 16(2), 290-296. https://doi.org/10.5713/ajas.2003.290

Soekarto, S. T. (2012). Jurnal Teknologi Dan Industri Pangan, 23(1), 107-116. https://doi.org/10.6066/5303

Sriharti., \& Salim, T. (2010). Pemanfaatan sampah taman (rumput-rumputan) untuk pembuatan kompos. Prosiding Seminar Nasional Teknik Kimia "Kejuangan" ISSN 1693 - 4393 Pengembangan Teknologi Kimia Untuk Pengolahan Sumber Daya Alam Indonesia Yogyakarta, 2005, 1-8.

Suryani, A. E., Anggraeni, A. S., Istiqomah, L., Damayanti, E., \& Karimy, M. F. (2021). Isolation and identification of phytate-degrading yeast from traditional fermented food. Biodiversitas Journal of Biological Diversity, 22(2), 866-873. https:// doi.org/10.13057/biodiv/d220241

Uauy, R., Kurpad, A., Tano-Debrah, K., Otoo, G. E., Aaron, G. A., Toride, Y., \& Ghosh, S. (2015). Protein and amino acids in infant and young child nutrition. J Nutr Sci Vitaminol, 61, 192-194.

Wang, Y., Cui, L. Y., Zeng, R. C., Li, S. Q., Zou, Y. H., \& Han, E. H. (2017). In vitro degradation of pure magnesiumThe effects of glucose and/or amino acid. Materials, 10(7). https://doi.org/ 10.3390/ma10070725

Wembabazi, E., Mugisha, P. J., Ratibu, A., Wendiro, D., Kyambadde, J., \& Vuzi, P. C. (2015). Spectroscopic analysis of heterogeneous biocatalysts for biodiesel production from expired sunflower cooking oil. Journal of Spectroscopy, 2015. https://doi.org/10. 1155/2015/714396

Wowor, A. R. Y., Bagau, B., Untu, I., \& Liwe, H. (2015). Kandungan protein kasar, kalsium, dan fosfor tepung limbah udang sebagai bahan pakan yang diolah dengan asam asetat (Ch3Cooh). Zootec, 35(1), 1. https:// doi.org/10.35792/zot.35.1.2015.6380

Yonata, D., Aminah, S., \& Hersoelistyorini, W. (2017). Kadar kalsium dan karakteristik fisik tepung cangkang telur unggas dengan perendaman berbagai pelarut. Jurnal Pangan Dan Gizi, 7(2), 82-93. 